\title{
THE INFLUENCE OF HONEY BEE (APIS MELLIFERA) DRONE AGE ON VOLUME OF SEMEN AND VIABILITY OF SPERMATOZOA
}

\author{
Krystyna Czekońska ${ }^{1 *}$, \\ Bożena Chuda-Mickiewicz², Pawel Chorbiński \\ ${ }^{1}$ Department of Pomology and Apiculture, Agricultural University, \\ 29 Listopada 54, 31-425 Krakow, Poland \\ ${ }^{2}$ Department of Zoology and Apiculture, West Pomeranian University of \\ Technology, Doktora Judyma 20, 71-466 Szczecin, Poland \\ ${ }^{3}$ Department of Epizootiology and Veterinary Administration with Clinic, University of \\ Environmental and Life Sciences, pl. Grunwaldzki 45; 50-366 Wrocław, Poland \\ *corresponding author: k.czekonska@ogr.ur.krakow.pl \\ Received 13 November 2012; accepted 06 March 2013 \\ $\mathrm{S}$ u m m a r y \\ A comparison was done of the volume of semen and viability of spermatozoa collected from \\ drones at ages 15, 20, 25 and 30 days. The drones originated from different queens and were \\ reared in different environments. Semen volume was determined by measuring the filled length \\ of a capillary. Percentages of live and dead spermatozoa were determined by SYBR-14/propidium \\ iodide fluorescence staining and flow cytometry. The volume of semen collected from drones ranged \\ from 0.5 to $1.3 \mu \mathrm{L}$. The mean volume of semen significantly decreased with drone age. Sperm \\ viability increased significantly with drone age.
}

Keywords: Apis mellifera, honey bee, drone, age, sperm viability.

\section{INTRODUCTION}

Honey bee (Apis mellifera) drones develop from unfertilized eggs. Their development takes 24 days: the egg 3 days, larva 6 days, prepupa and pupa 15 days (Winston, 1987). Spermatogenesis starts at the larval stage and spermiogenesis ends at the pupal stage (Bishop, 1920; Hoage and Kesse1, 1968). During the first week of adult life, spermatozoa are transferred from the testes to seminal vesicles, where they are stored until copulation (Snodgrass, 1956). The testes are largest during the pupal stage, and later degenerate (Snodgrass, 1956; Winston, 1987; Page and Peng, 2001).

Drones are not able to copulate immediately after emergence. Copulation and transfer of the spermatozoa from the seminal vesicles to the everted endophallus becomes possible when drones are 10-12 days old (Woyke, 1955; Woyke and
Ruttner, 1958, 1976). As drones age, the color and viscosity of their semen changes (Woyke and Jasiński, 1978; Cobey, 2007). The semen of 2-week-old drones is yellowish and fluid; the semen of 4-week-old drones is brown and more viscous. Spermatozoa of old drones are less viable but their motility does not change (Locke and Peng, 1993).

Drones aged 10-21 days are considered most suitable for natural and artificial insemination (Woyke and Ruttner, 1958; Woyke and Jasiński, 1978; Harbo, 1986). Drones younger than 10 days are immature, and the semen of those older than 21 days is too viscous. Queens inseminated with viscous semen transfer fewer spermatozoa in their spermatheca and have difficulty expelling excess semen from their oviducts, which become plugged (Woyke and Jasiński, 1978). 
Fertility of the queen depends on the quantity and quality of semen stored in her spermatheca. During natural mating the queen is inseminated by 3-17 drones (Woyke, 1960; Adams et al., 1977; Kraus et al., 2003). To obtain $8 \mu$ of semen for artificial insemination requires the use of 8-80 drones (Bobrzecki, 1968; Prabucki et al., 1992). When there are problems with semen collection, a large number of drones have to be used for artificial insemination (Woyke and Ruttner, 1958; Prabucki et al., 1992; Chuda-Mickiewicz and Prabucki, 1993; Woyke, 2008).

One drone can produce 1.5-1.7 $\mu \mathrm{l}$ of semen (Woyke, 1960). Usually $1.0 \mu \mathrm{l}$ is collected to a syringe during artificial insemination. This is equivalent to 7.5 million spermatozoa (Woyke, 1960). Amount and quality of the semen is important for the success of both natural and artificial insemination. Queens inseminated with semen of poor quality can be superseded at an earlier age (Woyke and Ruttner, 1976; Cobey 2007). According to Locke and Peng (1993) spermatozoa viability decreases with drone age. Moreover, viability of semen produced by drones stored after emergence in higher temperatures is lower (Bieńkowska et al., 2011). It is not clear, however, if the environment in which drones develop, affect their sperm viability. In this study we compared the volume of semen and the viability of spermatozoa from drones of different ages. The drones originated from different queens and were reared in different environments.

\section{MATERIAL AND METHODS}

The research used 120 drones (A. m. carnica). The drones were sons of three unrelated queens and were reared in three different localities: Krakow, Wrocław, and Szczecin. The queens were caged on an empty drone comb for 24 hours. This procedure was repeated 4 times at 5-day intervals to obtain drones at the ages of $15,20,25$, and 30 days. Drones were reared by Ruttner's (1976) method. Before the experiment the drones were transferred to wooden cages $(130 \times 115 \times 70 \mathrm{~mm})$ together with 150 workers. The cages were supplied with candy and water.

Semen was collected using a microcapillary calibrated to $1 \mu \mathrm{L}$. Semen volume was determined by measuring the filled length of the capillary with calipers. The semen was diluted in $1000 \mu \mathrm{L}$ of Kiev buffer $(0.3 \mathrm{~g} \mathrm{D}+$ glucose, $0.41 \mathrm{~g}$ potassium chloride, $0.21 \mathrm{~g}$ sodium bicarbonate, $2.43 \mathrm{~g}$ sodium citrate per $100 \mathrm{~mL}$ deionized sterile water) (Moritz, 1984).

Each of the three queens $(\mathrm{A}, \mathrm{B}, \mathrm{C})$ were represented by 10 drones in each of the four age groups $(15,20,25,30$ days). In total, 120 samples of semen were analyzed. In each sample the percentages of live and dead spermatozoa were determined by SYBR-14/propidium iodide (IP) fluorescence staining with the LIVE/ DEAD Sperm Viability Kit (Molecular Probes L-7011). Using this sperm viability kit, live and dead sperm were stained green and red, respectively. From each sample, two $300 \mu \mathrm{L}$ portions of diluted semen were collected; $5 \mu \mathrm{L}$ SYBR 14 (stock solution, deionized sterile water 1:50) was added and then incubated for 5 minutes at $36^{\circ} \mathrm{C}$. Then, $4 \mu \mathrm{L}$ propidium iodide (PI) was added and stirred. The counts were obtained by flow cytometry (Becton Dickinson FACSCalibur, USA) with a $488 \mathrm{~nm}$ argon laser. Green florescence was measured in the LFL1 channel and red in channels LFL2 and LFL3, using the manufacturer's fluorescence compensation filters (Tofilski et al., 2012). The sperm viability was measured within $20 \mathrm{~min}$ from semen collection.

The data were analyzed using WinMDI 2.8 software. Nested ANOVA was used for statistical analysis. Percentage data were arcsin-transformed (Sokal and Rohlf, 1981). 
Table 1 .

Volume of semen and viability of sperm from drones originating from three different honey bee queens

\begin{tabular}{||l|c|c|c|c||}
\hline \multirow{2}{*}{ Queen } & \multirow{2}{*}{$\mathrm{N}$} & \multicolumn{2}{|c|}{ Volume of semen $(\mu \mathrm{l})$} & \begin{tabular}{c} 
Sperm viability \\
\cline { 3 - 4 }
\end{tabular} \\
\cline { 3 - 4 } & mean $\pm \mathrm{SD}$ & range & $($ mean \pm SD) \\
\hline $\mathrm{A}$ & 40 & $0.95 \pm 0.19$ & $0.55-1.34$ & $88.49 \pm 4.53$ \\
\hline $\mathrm{B}$ & 40 & $0.91 \pm 0.20$ & $0.50-1.32$ & $89.64 \pm 3.71$ \\
\hline $\mathrm{C}$ & 40 & $0.95 \pm 0.20$ & $0.55-1.29$ & $89.33 \pm 4.60$ \\
\hline \hline
\end{tabular}

Volume of semen and viability of sperm from drones of different ages

\begin{tabular}{||l|c|c|c|c||}
\hline \hline \multirow{2}{*}{$\begin{array}{l}\text { Age } \\
\text { (days) }\end{array}$} & \multirow{2}{*}{$\mathrm{N}$} & \multicolumn{2}{|c|}{ Volume of semen $(\mu \mathrm{l})$} & \begin{tabular}{c} 
Sperm viability \\
\cline { 3 - 4 }
\end{tabular} \\
\cline { 3 - 4 } & mean $\pm \mathrm{SD}$ & range & $($ mean $\pm \mathrm{SD})$ \\
\hline 15 & 30 & $1.02 \pm 0.22 \mathrm{a}^{*}$ & $0.56-1.34$ & $87.8 \pm 4.93 \mathrm{a}$ \\
\hline 20 & 30 & $0.93 \pm 0.17 \mathrm{ab}$ & $0.63-1.27$ & $88.0 \pm 4.38 \mathrm{a}$ \\
\hline 25 & 30 & $0.91 \pm 0.21 \mathrm{~b}$ & $0.55-1.32$ & $89.4 \pm 3.73 \mathrm{ab}$ \\
\hline 30 & 30 & $0.88 \pm 0.19 \mathrm{~b}$ & $0.50-1.25$ & $91.4 \pm 3.12 \mathrm{~b}$ \\
\hline
\end{tabular}

Means with different letters within columns differ significantly $(\mathrm{p}<0.05)$.

\section{RESULTS}

With age, the viscosity of semen increased and its color changed from light cream to dark cream. The mean volume of semen collected from one drone was $0.93 \mu \mathrm{L}$ (Tab. 1). The volume of semen collected from drones originating from different queens did not differ significantly $(\mathrm{F}=0.611, \mathrm{df}=2,108, \mathrm{p}=0.545)$. The mean volume of collected semen decreased with drone age $(\mathrm{F}=2.942$, $\mathrm{df}=3,108$, $\mathrm{p}=0.036)($ Tab. 2).

The mean viability of sperm was $89.15 \%$ (Tab. 1). The viability did not differ between drones originating from different queens $(\mathrm{F}=1.100, \mathrm{df}=2,108, \mathrm{p}=0.335)$. Sperm viability increased significantly with drone age $(\mathrm{F}=6.270, \mathrm{df}=3,108$, $\mathrm{p}<0.001$ ) (Tab. 2).

\section{DISCUSSION}

The observed reduction of semen volume with drone age, confirms earlier findings (Woyke and Jasiński, 1978; Locke and Peng, 1993). The viability of spermatozoa did not differ between drones originating from different queens. Locke and Peng (1993) reported reduction of sperm viability from $86 \%$ in 14 -day-old drones to $81 \%$ in 28 -day-old drones. In this study we found an increase of sperm viability from $88 \%$ in 15 -day-old drones to $91 \%$ in 30-day-old drones.

One explanation for the increase of sperm viability with age may be related to the gradual maturation of drones. Possibly the drones are able to evert the endophallus and ejaculate before full sexual maturity. In younger drones, the amount of semen remaining in seminal vesicles after ejaculation is higher, and the number of spermatozoa in ejaculate increases with age (Rhodes, 2008). Full maturity of drones may be related not only to more efficient emptying of their seminal vesicles but also to higher sperm viability.

Another possible explanation of increased sperm viability with age might be that drones with higher sperm viability have a higher survival. Drones developing in a better environment might have both longer lives and more viable sperm. In these circumstances, the observed increase in sperm viability could be an effect of poor survival of drones with low sperm viability. In other studies, only $4 \%$ of drones survived to the age of 35 days (Rhodes et al., 2011). 


\section{CONCLUSIONS}

The volume of semen collected from one drone decreased with its age.

The sperm viability increased with drone age.

\section{ACKNOWLEDGEMENTS}

We wish to thank Iwona Zbyryt for her technical assistance and Adam Tofilski for comments on an earlier version of the manuscript. This study was financed from the National Science Centre funds based on decision No. DEC-2011/01/B/NZ9/00213.

\section{REFERENCES}

Adams J., Rothman E. D., Kerr W. E., Paulino Z. L. (1977) - Estimation of the number of sex alleles and queen matings from diploid male frequencies in a population of Apis mellifera. Genetics, 86: 583-96.

Bieńkowska M., Panasiuk B., Węgrzynowicz P., Gerula D. (2011) - The effect of different termal conditions on drone semen quality and number of spermatozoa entering the spermatheca of queen bee. J. Apic. Sci., 55(2): 161-168.

Bishop G. H. (1920) - Fertilization in the honey-bee. J. Exp. Zool. 31: 225-266.

Bobrzecki J. (1968) - Badania nad wpływem wychowu na dojrzałość płciową trutni i ich przydatność do sztucznego unasienienia [Studies on the effects of rearing on the sexual maturity of drones and their suitability to artificial insemination]. Zesz. Nauk. WSR Olsztyn, 24(624): 197-220.

Chuda-Mickiewicz B., Prabucki J. (1993) - Podejmowanie czerwienia przez matki pszczele przetrzymywane w skrzynkach w asyście swobodnie oblatujących się pszczół [Undertaking oviposition by honeybee queens kept in nursery cages with free flying bees]. Pszczeln. Zesz. Nauk., 37: 23-31.

Cobey S. W. (2007) - Comparison studies of instrumentally inseminated and naturally mated honey bee queens and factors affecting their performance. Apidologie, 38: 390-410.
Harbo J. R. (1986) - Propagation and instrumental insemination, in: Rinderer, T. E. (Ed.) Bee genetics and breeding. Academic Press, INC, Orlando, Florida, pp. 361-389.

Hoage T. R., Kessel R. G. (1968) - An electron microscope study of the process of differentiation during spermatogenesis in the drone honey bee (Apis mellifera L.) with special reference to centriole replication and elimination. J. Ultrast. Res., 24: 6-32.

Kraus F. B., Neumann P., Scharpenberg H., van Praagh J., Moritz R. F. A. (2003) - Male fitness of honeybee colonies (Apis mellifera L.). J. Evol. Biol., 16: 914-920.

Locke S. J., Peng Y. S. (1993) - The effects of drone age, semen storage and contamination on semen quality in the honeybee (Apis mellifera). Physiol. Entomol., 18: 144-148.

Moritz R. F. A. (1984) - The effect of different diluents on insemination success in the honeybee using mixed semen. J. Apic. Res., 23: 164-167.

Page R. E., Peng C. Y. S. (2001) - Age and development in social insects with emphasis on the honey bee, Apis mellifera L. Exp. Gerontol., 36: 695-711.

Prabucki J., Chuda-Mickiewicz B., Kochaniak D. (1992) - Ocena kondycji rozpłodowej trutni wychowywanych w rodzinach porażonych Varroa jacobsoni Oud. [Evaluation of the reproductive condition of drones bred in bee colonies infested with Varroa jacobsoni Oud.] Annales UMCS Lublin, Polonia, 67(9): 47-54.

Rhodes J. W. (2008) - Semen production in drone honeybees. RIRDC Pub. No. 08/130. [online]https://rirdc.infoservices.com.au/ downloads/08-130 (access on 09.05.2013).

Rhodes J. W., Harden S., SpoonerHart R., Anderson D. L., Wheen G. (2011) - Effects of age, season and genetics on semen and sperm production in Apis mellifera drones. Apidologie, 42: 29-38.

Ruttner F. (1976) - The instrumental insemination of the queen bee. Apimondia, Bucharest, pp. 1-124. 
Snodgrass R. E. (1956) - Anatomy of the honey bee. Cornell University Press, Ithaca, NY, pp. 290-298.

Sokal R. R., Rohlf F.J , (1981) - Biometry.

W. H. Freeman and Company, New York.

Tofilski A., Chuda-Mickiewicz B., Czekońska K., Chorbiński P., (2012)

- Flow cytometry evidence about sperm competition in honey bee (Apis mellifera). Apidologie, 43: 63-70.

Winston M. L. (1987) - The Biology of the Honey Bee. Harvard University Press.

Woyke J. (1955) - Multiple mating of the honeybee queen (Apis mellifica L.) in one nuptial flight. Bull. Acad. Pol. Sci., Cl II 3(5): 175-180.

Woyke J. (1960) - Naturalne i sztuczne unasienianie matek pszczelich [Natural and instrumental insemination of queen bees]. Pszczeln. Zesz. Nauk., 4: 183-275.
Woyke J. (2008) - Why the eversion of the endophallus of honey bee drone stops at the pasty everted stage and significance of this. Apidologie, 39: 627-636.

Woyke J., Ruttner F. (1958) - An anatomical study of the mating process in honey bee. Bee World, 39: 3-18.

Woyke J., Jasiński Z. (1978) - Influence of age of drones on the results of instrumental insemination of honeybee queens. Apidologie, 9: 203-212.

Woyke J., Ruttner F. (1976) - Results, in: Ruttner F. (Ed.) The instrumental insemination of the queen bee, Apimondia, Bucharest, pp. 87-92.

\title{
OBJĘTOŚĆ NASIENIA I ŻYWOTNOŚĆ PLEMNIKÓW TRUTNI PSZCZOLY MIODNEJ (APIS MELLIFERA) W ZALEŻNOŚCI OD ICH WIEKU
}

\author{
Czekońska K., Chuda-Mickiewicz B., Chorbiński P. \\ $\mathrm{S} t \mathrm{r}$ e s z c z e n i e
}

Ilość i jakość nasienia trutni decyduje o skuteczności naturalnego i sztucznego unasieniania matek pszczelich. Unasienienie matek nasieniem o obniżonej żywotności plemników może mieć wpływ na czas ich użytkowania. Według wcześniejszych badań, żywotność plemników spada $\mathrm{z}$ wiekiem trutni. Nie wiemy czy obniżanie się żywotności plemników z wiekiem trutni zależy tylko od wieku czy też może mieć na to wpływ ich pochodzenie. Celem badań było porównanie objętości nasienia i żywotności plemników trutni w tym samym wieku, pochodzących od różnych matek, utrzymywanych w różnych warunkach.

Trutnie Apis mellifera pochodziły od niespokrewnionych matek z rodzin znajdujących się w trzech pasiekach, w Krakowie, Wrocławiu i w Szczecinie. W każdej rodzinie, w tym samym czasie, co 5 dni, rozpoczynano wychów trutni. Badania objętości nasienia i żywotności plemników wykonywano u trutni w wieku 15, 20, 25 i 30 dni. W sumie zbadano nasienie 120 trutni, pobrane od 30 osobników z każdej klasy wiekowej, po 10 od tej samej matki. Objętość nasienia mierzono mikrokapilarą o wyskalowanej objętości, z dokładnością do $0,1 \mu \mathrm{L}$. Udział plemników żywych i martwych oceniano metodą fluorescencyjną SYBR-14/jodek propidyny z zastosowaniem cytometru przepływowego FACSCalibur.

Objętość nasienia pobranego od jednego trutnia wynosiła od 0,50 do $1,34 \mu \mathrm{L}$, żywotność plemników od 87,8 do $91,4 \%$. Objętość nasienia trutni pochodzących od różnych matek nie różniła się istotnie $(\mathrm{p}=0,545)$, natomiast malała wraz $\mathrm{z}$ wiekiem trutni $(\mathrm{p}=0,036)$. Żywotność plemników trutni $\mathrm{w}$ zależności, od której matki pochodziły nie różniła się $(\mathrm{p}=0,335)$, ale wraz $\mathrm{z}$ wiekiem trutni znacząco wzrosła $(\mathrm{p}<0,001)$. Wzrost udziału żywych plemników z wiekiem trutni 
był prawdopodobnie efektem naturalnej selekcji polegającej na szybszym wymieraniu słabszych osobników o prawdopodobnie gorszej jakości nasienia.

Słowa kluczowe: Apis mellifera, pszczoła miodna, truteń, wiek, żywotność plemników. 